\title{
AZ AGILIS MÓDSZERTANOK MEGÍTÉLÉSE A BEOSZTOTTAK ÉS VEZETŐK SZEMSZÖGÉBŐL
}

\begin{abstract}
A különböző területeken alkalmazott szoftverfejlesztési módszerek erőteljes mértékben határozzák meg a vállalatok alapvető működését. Mivel az információs társadalomban felértékelődött a szoftverek szerepe, így elmondható, hogy jelenleg radikális változásoknak vagyunk tanúi, amelyek kihatással vannak a szervezet struktúrájára és vezetésére egyaránt. $\mathrm{A}$ 2000-es évek elején a korábbi klasszikus szoftverfejlesztési modellek mellett - mint például az úgynevezett vízeséses modell - a gyorsuló technológiai és piaci fejlődésre válaszként megjelent egy új módszertan, az agilis. Ez az irányzat és ennek eszközei (például a Scrum, a Kanban vagy az eXtreme Programming) sokkal inkább koncentrálnak a piaci változásokra, az ügyféllel történő folyamatos kommunikációra, és a visszajelzések alapján a fejlesztés irányának rugalmas kezelésére, mint a korábbi modellek. Ezek bevezetése Magyarországon megközelítőleg 5-6 évvel ezelőtt kezdődött el, és a legtöbb szervezet még jelenleg is tanulja a módszertanok hatékony alkalmazását. Az agilis eszközök alkalmazása a szervezet egészére kihat, így annak a bevezetését, az implementálás sikerességét, a különböző elemek hatékonyságát a beosztottak és a vezetők másképpen ítélik meg. Jelen cikk ezeket, az eltérő nézőpontok közötti hasonlóságokat és különbségeket mutatja be agilis szoftverfejlesztéssel kapcsolatos szakmai közösségekben terjesztett kérdőíves megkérdezés segítségével.
\end{abstract}

\section{Kulcsszavak: agilis szoftverfejlesztés, beosztottak és vezetők, Scrum, Kanban, eXtreme Programming (XP)}

$\mathrm{N}$ apjainkban a termékfejlesztés egyik legfontosabb megközelítésévé vált a vevők és felhasználók folyamatos bevonása a fejlesztési folyamatokba, mint a TQM (TotalQuality Management, teljes körü minőségmenedzsment) vezetési filozófia egyik alapelvének alkalmazása (Kiran, 2017). A korábbi klasszikus szoftverfejlesztési modellek „merev” kialakításúak, így azok az idő múlásával egyre kevésbé bizonyultak hatékonynak a lineáris jelleg, a lépések szoros egymásutánisága miatt. Az alkalmazott szoftverfejlesztési modellek folyamatosan változtak és alakultak a vevői igényekhez, azonban a rugalmasság kellő beépülése csak a 2000-es évek elején, az agilis módszertanok létrejöttével valósult meg. Ez a módszertan alapvetően eltér a korábban alkalmazott módszerektől, mivel igen gyorsan teszi lehetővé a felmerülő változások menedzselését a termékfejlesztés irányába (Schön et al., 2017). Ezeknek a rövid távon bekövetkező változásoknak a megvalósítása rugalmas hozzáállást igényel a követelménytervezésben is, amelyet a szervezetek értékalapú gondolkodással tudnak megvalósítani, a korábbi tervalapú megközelítés helyett. A gyakorlatban éppen ezért az agilis módszertanokat gyakran kombinálják az emberközpontú tervezés aspektusaival. Így az eredménytermékkel kapcsolatos követelményeket a felhasználó szemszögéből határozzák meg a különböző követelménylisták írása helyett. A korábbi modellekkel ellentétben itt tehát a határidők és a költségek helyett a követelmények folyamatos menedzselése a kulcsfontosságú tényező (1. ábra).

Webster szerint az információs társadalom legfőbb jellemzője, hogy abban nemcsak technológiai, hanem gazdasági, foglalkozásszerkezeti, térszerkezeti és kulturális változások is zajlanak (Webster, 2006). Az információs és kommunikációs technológiák alapjaiban formálták át a társadalmak müködését (beleértve a politikát, a kultúrát és a hétköznapi életet is). Ma már a gazdaság minden területén az információs jellegü munkavégzés dominál az informatikai szektor újabb és újabb szoftvertermékeinek köszönhetően (Pintér, 2007).

1. ábra

A klasszikus és az agilis módszertanok kiindulópontjai közötti eltérés bemutatása

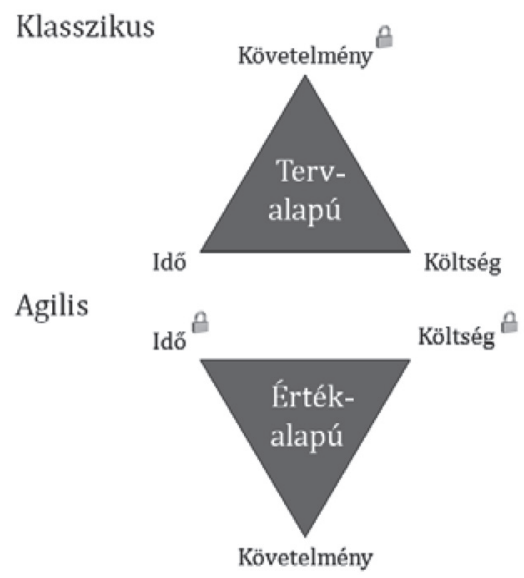

Forrás: Schön et al., 2017 megközelitését is felhasználva

Az információs technológia világa tehát rohamosan fejlödik, így a mai szoftverpiaci szereplök ahhoz, hogy ne maradjanak le a hatalmas versenyben, új megközelítéseket és módszertanokat alakítottak ki. Ehhez elengedhetetlen tényező a megfelelő rugalmasság és a változásmenedzsment: az agilis módszertanok bevezetése és alkalmazása morfogenetikus változásnak tekinthető egy szervezet életében (Pataki, 2014). Ennek az implementálását a különböző szervezetek különféle módokon, igen eltérő agilis eszközök alkalmazásával végzik, aminek a legfőbb oka, 
hogy a szoftverfejlesztés minden tekintetben változatosabb, mint korábban volt. Így az aktuális trendeknek megfelelő projektmenedzsment-eszközök a cégek életében igen változatos arányban és módon vannak jelen.

Jelen cikk az agilis módszertanok megítélésbeli hasonlóságait és különbségeit tárja fel, a módszertan erősségein és gyengeségein túl részletesen vizsgálva, hogy a beosztottak és a vezető pozícióban dolgozók véleménye szerint milyen igények motiválták az agilis módszerek bevezetését, miben látják az egyes agilis projektek sikerességének vagy sikertelenségének fö okait, mennyiben változik a használt agilis eszközökkel kapcsolatos megbeszélések és az adminisztráció mennyiségének a megítélése a beosztottak és a vezetők szemszögéből.

\section{A kutatás témájának háttere: az agilis módszertan}

A szoftverfejlesztés lassan életünk minden területét érinti valamilyen formában, egyre inkább olyan eszközöket használunk, amelyek szoftverrel müködnek. A különböző rendszerek fejlesztése rendkívül összetett és költséges folyamat, ami nem kifejezetten a használt eszközök és technológiák, sokkal inkább az emberi tényezők (többek közt a kommunikáció, az együttmüködési és problémamegoldó képesség) korlátainak köszönhető (Furnham, 2006). Az eredményességet meghatározó különböző emberi összetevők magas szintjének elérése így szükséges alapfeltétele az agilis módszertanok alkalmazhatóságának is.

A rugalmasság teljes hiánya miatt a sokáig használt, iterációmentes, vízesés jellegű szoftverfejlesztési modellek (Sommerville, 2010) egyre kevésbé bizonyultak hatékonynak. A rugalmasság kellő beépülése a többi iterációs, már szintén klasszikusnak tekinthető szoftverfejlesztési modellben sem tudott eléggé megvalósulni (Schön et al., 2017). Mivel ezekben a modellekben nincs elég lehetőség a kapcsolattartásra (akár a vevővel, akár a projekttagok között), illetve nem megoldott az esetleges módosítások kezelése és beépítése a folyamatba, így létrejött a 2000es évek elején az agilis módszertan, aminek a gyökerei a lean menedzsment és a kaizen módszer elemeire vezethetők vissza (Dingsøyr et al., 2012). A kaizen olyan filozófia és módszertan, amit a szervezetekben a különböző folyamatok hatékonyságának növelésére használnak a TQM szerinti folyamatos tökéletesítést támogató vállalati kultúra létrehozására (Tasi, 2011). Ezt arra építve teszi, hogy minden probléma egyben lehetőség a fejlődésre, valamint facilitálva, hogy a szervezeti tanuláshoz a szervezet minden tagjának elkötelezettségére és részvételére van szükség (Medinilla, 2014). A lean menedzsment pedig az agilis módszertanok alapját képező értékteremtés stratégiai és operatív szintjének meghatározó formálójává vált az elmúlt évtizedekben, nem beszélve arról, hogy a lean menedzsment adaptálásának egyik legnagyobb kihívásaként jelenik meg a vezető gondolkodásmódjának a változása is (Losonczi, 2010).

Az agilitás az elmúlt 20 év egyik fontos fogalma, amely a gyártási és a szoftverfejlesztési folyamatok, valamint a projektmenedzsment-tevékenységek kapcsán való- sult meg több-kevesebb sikerrel a különböző szervezetek életében. Ennek ellenére az agilis megközelítés vizsgálata nem része a magyar akadémiai diskurzusnak, pedig a téma évek óta jelen van a hazai szoftverfejlesztés, vagy projektmenedzsment relevanciájú szakmai fórumokon (Klimkó, 2014).

Az agilis kifejezést ma már kiterjesztett értelemben, minőségjelzőként is gyakran használják, amit így az évek alatt több fogalommal füztek össze, mint például termékfejlesztés (Stare, 2014), szervezet (Cummins, 2017), vagy projektmenedzsment.

Bár definíció szerint a projekt egyedi tevékenység, ugyanakkor Wysocky felismerte azt, hogy releváns különbség van az egyes projekttípusokban az egyediség és a kockázatosság aldimenziói mentén. Ezek az eltérések a „rugalmasság” és az „,adaptív képesség” megfelelő adagolásával kezelhetők. Wysocky szerint ,,agilis projektmenedzsmentről', akkor beszélünk, amikor a cél maga jól definiált, de az elérés módja nem meghatározható. Ilyen esetekben a projektéletciklus iteratív és inkrementális szakaszolása nyújthat megoldást (Wysocky, 2009).

Chin megközelítése ehhez egészen hasonló, aki az „,agilis projektmenedzsment” fogalomhasználatának a létjogosultságát a különféle projektek eltérö bizonytalanságával indokolja (Chin, 2004).

DeCarlo már a bizonytalanság helyett a gyors változással, a magas komplexitással vagy kockázattal indokolja az ,extrém projektmenedzsment” alkalmazását, az általa „stresszesnek” titulált projektek esetén (DeCarlo, 2004). Ez a megközelítés holisztikus, emberközpontú és projektmenedzsmentjét az üzlet alaptevékenysége és a valóság vezérli.

$\mathrm{Az}$ agilis egy együttmüködésre építő, folyamatosan fejlődő, minőségfókuszú fejlesztési megközelítés. Ez az irányzat nem feltétlenül használható minden cég számára, legfőképpen a megfelelő méretü, létszámú, szaktudással és szervezeti érettséggel rendelkező szoftverfejlesztési vállalatoknál lehet meghatározó. Ez egybevág a kontingenciaelmélettel, amely szerint a megfelelő szervezeti struktúrát az aktuális környezeti feltételekhez és a cég belső adottságaihoz kell igazítani, így nem létezik olyan megoldás, amely mindig hatékonyan müködik (Dobák Antal, 2010).

Az alkalmazott agilis projektmenedzsment-eszközök és a különböző szervezetikultúra-típusok között kapcsolat van, így azokat annak megfelelően kell kiválasztani a hatékony eredmény elérése érdekében (Bunyakiati - Surachaikulwattana, 2016). Az irányzat követői 2001-ben megfogalmazták az Agilis Kiáltványt (Beck et al., 2001), ami a módszer legfontosabb elemeit írja le. Ez a dokumentum tartalmazza az agilis fejlesztéssel kapcsolatos legfőbb, általános irányelveket, amely a kapcsolódó projektmenedzsment-eszközökkel kapcsolatos terminus technikusok definiálásával segíti a kutatás elméleti hátterét. A fogalmak ismertetése nélkülözhetetlen a téma és az empirikus felmérésben szereplő eredmények megértéséhez.

$\mathrm{Az}$ agilis módszertanoknak számtalan elönyük van, amelyek közül Boehm (2002) alapján kiemelendő - az iteratív folyamatoknak köszönhetően - a gyors reagálási 
képesség a céget vagy projektet érintő változásokra. Ez vezetői szemszögből releváns szempont, ugyanúgy, mint az üzleti értékek által vezérelt priorizálás, ami egy agilis eszköz - a Product Backlog lista - segítségével valósul meg. Előny továbbá a valós költségkontroll, ugyanis itt a projekthatókör (scope) helyett a költségeket és a határidőket rögzítették. A beosztottak szemszögéből nagy előnye a módszertannak az önszerveződő csapatokon keresztül történő hatékony együttműködés a cél megvalósítása érdekében, valamint a folyamatosan fejlődő minőség középpontba állítása.

Mivel a szoftverfejlesztési projekteknél gyakori, hogy a megrendelö és a fejlesztő „elbeszélnek” egymás mellett, így az agilis szemléletủ projektkontroll egyik legfontosabb eszköze a megrendelő bevonása (Kosztyán, 2015). Agilis fejlesztés során az elkészült terméket tehát bizonyos időközönként bemutatják az ügyfélnek, akinek így folyamatosan (rugalmasan) van lehetősége reagálni - így a megrendelő és a fejlesztésért felelős agilis csapat együttesen alakítják és folyamatosan pontosítják a termék specifikációját. A közös munka során a végtermék tehát nincs kőbe vésve, így az a piaci változásokra, az új technológiák megjelenésére, egyéb módosítási igényekre is rugalmasan és hatékonyan tud reagálni.

Fontos megemlíteni, hogy az agilis módszerek alkalmazásának buktatói és korlátai is vannak, amelyek Turk és társai szerint két fö csoportra oszthatók, így azok a folyamatban részt vevő személyekhez, vagy az előállított szoftvertermékhez köthetők. Az első csoportba tartoznak az olyan esetek például, amikor a projekten dolgozók fizikailag nem egy térben tartózkodnak. A földrajzi távolságok kommunikációs nehézségeket okoznak, illetve nem támogatják a személyes interakciókat. Ezek hiányában a programkód mögötti alapos és megfelelő dokumentáció az, ami prioritást élvez. Így a teljes folyamat biztosan nem lesz agilis, legfeljebb az eszköztár bizonyos elemei alkalmazhatók a fejlesztés során. Hasonló probléma merülhet fel alvállalkozók bevonása esetén is, hiszen a folyamatban részt vevő külsős munkatársak legfőbb feladata a szerződésben előre definiált feladatok elvégzése. Ebben az esetben az agilitás csak részben biztosítható, ha a szerződésben rögzítik a fix kereteket és a variálható leszállítandókat. Ide sorolható még az az eset is, amikor a szervezetben nagy csapatok müködnek. Hiszen a túlzott kommunikációs lehetőségek az agilis működés hatékonyságának a rovására mennek, ráadásul a személyes interakciók (például review megbeszélések) gyakoriságát is túlzottá teszik.

A másik csoportba sorolható korlátok az előállítani kívánt termékhez köthetők: az agilis módszerek nem alkalmasak olyan szoftverek fejlesztésére, amely során a korábbi szoftvertermékek már megírt kódját újra felhasználnák. A munkát tehát előre gyártott komponensekkel és újra felhasználható kódokkal nem tehetjük szabványossá, mert az nagyfokú dokumentációt igényel és a minőség rovására is megy, ami így ütközik az agilis irányelvekkel. Tisztán agilis müködés nehezen képzelhető el továbbá biztonságkritikus rendszerek fejlesztése során is, hiszen itt az alapos dokumentáció és az azoknak való minőségi megfeleltetés, valamint a folyamatos tesztelés az, ami egy sokkal merevebb (például vízesés jellegü) folyamatot kíván. Ugyanez igaz komplex rendszerek fejlesztése esetén is, ahol a különböző részek külön-külön és együttesen történő müködése nagyobb fokú menedzsment-ellenőrzést és formalizált folyamatot igényel (Turk et al., 2005).

\section{Agilis projektmenedzsment-eszközök}

Az agilis módszertanon belül számos eszközt találunk, amelyek lehetővé teszik a kellő rugalmasság integrálását a szoftverfejlesztési folyamatokba, valamint a vezetők és a beosztottak számára is útmutatást nyújtanak a változó igényekre történő reagáláshoz. Ezek közül a legismertebbek a Scrum, a Kanban és az eXtreme Programming (VersionOne, 2017).

\section{A Scrum}

A Scrum egy keretrendszer, ami bizonyos mértékig szabályozza, hogy mi és hogyan tehető meg a fejlesztés során, ezzel elősegítve a hatékonyabb munkavégzést. Ugyan bizonyos elöírásokat meghatároz, vezetői szinten mégis leginkább a szervezetre, munkavállalói szinten pedig a projektcsapatra bízza, hogy ezek közül mely elemeket találják hasznosnak (Paulk et al., 2011).

A Scrum az iteratív fejlesztés egyik eszköze, ahol egy iteráció (a részletesebb tervezés és fejlesztés, illetve annak a bemutatása) néhány hetet fed le, majd indul elölről a folyamat. Az iteratív folyamat egy szakaszát, azaz egy iterációt a Scrum-ban sprintnek nevezik. Egy sprint tehát lényegében egy kisebb alprojekt, aminek van egy meghatározott időkerete (tipikusan 1-4 hét). Ezalatt az a tervezéstől az átadásig valamennyi fejlesztési folyamatot magába foglalja, a lefutása tehát olyan, mint a hagyományos szoftverfejlesztés vízesés modellje. Az elöre rögzített időkeret alatt az adott sprintre tervezett feladatokon nem lehet változtatni, valamint újat hozzáadni sem (Rasmusson, 2010).

A Scrum eszköztár legfontosabb alappillérei három dimenzió mentén helyezhetők el:

- Szerepkörök: Scrum Master, Product Owner, Team, - Ceremóniák: Sprint tervezés, Napi Scrum, Review,

- Dokumentumok: Product Backlog, Sprint Backlog, Burndown Chart.

Ezek az alappillérek szintén olyan kifejezésekkel hozhatók kapcsolatba, amelyek ismertetése elengedhetetlen a kutatás eredményeinek ismertetése során.

\section{Scrum - Szerepkörök}

Schwaber és Sutherland munkáját alapul véve elmondható, hogy a Scrum Master az a személy, aki a keretrendszer betartásáért felel (Schwaber - Sutherland, 2013). További feladatai közé tartozik, hogy elhárítson minden akadályt, ami a csapat útjába áll, hogy a tagok csakis a fejlesztéssel foglalkozhassanak. Ezen kívül rendkívül fontos szerepe van a rendszer folyamatos javításában, fejlesztésében, valamint ő végzi a csapat adminisztrációját és szervezi, illetve moderálja a megbeszéléseket is. 
A Product Owner felel a termékfejlesztés sikerességéért. Az egyik legfontosabb feladata, hogy felmérje az ügyfél igényeit, amiből összeállít egy - az aktuális iterációs szakaszra érvényes - követelményspecifikációt (Product Backlog dokumentáció).

A harmadik fontos szerepkör a Team, tehát a projektcsapat, amely (mint többszemélyes szereplö) a munka végrehajtásáért felelős. A csapat a hatékony problémamegoldás érdekében általában keresztfunkcionális, így különböző kompetenciákkal rendelkező tagokból és tipikusan 5-9 főből áll (Parker, 2015) - ugyanis ez az a létszám, ahol még optimális lehet az együttmüködés a csapaton belül.

\section{Scrum - Ceremóniák}

A három ceremónia közül az első a Sprint tervezése (Leit et al., 2017), amikor a Product Owner által priorizált feladatlistából az adott sprinthez annyi feladatot rendelnek, amennyit a meghatározott időkeret alatt el tudnak végezni. A Team tagok a sprintek során minden nap, egy előre meghatározott időpontban Napi Scrum (más néven Napi Stand-up) megbeszélést tartanak. A módszertan egyik legfontosabb eleme ez a napi találkozó, ahol a csapattagok egy megközelítőleg 15 perces álló megbeszélést tartanak. A célja, hogy elősegítse a kommunikációt, az együttmüködésben lehetővé tegye a szinergiát. A csapattagok meghatározzák, hogy pontosan mi az, amivel a legutóbbi megbeszélés óta hozzájárultak a projekt sikeréhez, illetve hogy a következő megbeszélésig mit tesznek majd ahhoz hozzá, valamint azonosítják a zavaró tényezőket. A sprintek végén sor kerül a Review megbeszélésre is, ami két részre bontható. Először bemutatják az elkészült részegységeket, majd átbeszélik az előző sprint tanulságait.

\section{Scrum - Dokumentumok}

Az előbbiekben említett Product Backlog tehát egy lista az ügyfél és a csapat által meghatározott követelményekről, funkcionalitásokról, amikkel a végső terméknek rendelkeznie kell. A Sprint Backlog pedig az a dokumentum, ahova a priorizálásnak megfelelően a Product Backlog legfelső elemei kerülnek. Ez tartalmazza tehát az adott iterációra vállalt feladatokat. A projekt előrehaladását pedig a Burndown Chart grafikon mutatja olyan módon, hogy az ordináta tengelyen jelöli a projekt során elvégzendő összes feladatot, az abszcisszán pedig a rendelkezésre álló időt. Ezek alapján kiszámítható az optimális haladás, amely így egy negatív meredekségű egyenes lesz. Segítségével minden csapattag és a vezetőség is láthatja, hogy az adott team az optimálishoz képest hogyan teljesít (Viscardi, 2013).

\section{Kanban}

A gyártás világából átvett Kanban egy jóval kevésbé előíró eszköz, mint a Scrum, azonban hasznos elemeket tartalmaz, melyek követése a szoftverfejlesztés területén is kifejezetten praktikus lehet. Mindössze három fö szabályt határoz meg: a vizualizáció és a Work In Progress (WIP) limit használata, valamint az átfutási idő mérése (Anderson, 2010).
Ezek közül a Kanban egyik legfontosabb szabálya a vizualizáció, ami egy úgynevezett Kanban tábla segítségével történik. A táblázat sorai a csapattagok, az oszlopok pedig a munkafolyamatok neveit tartalmazzák. A Kanban tábla lehetővé teszi a munkafolyamatok állapotának személyenként történő nyomon követését, ami vizuális viszszacsatolást biztosít a csapattagok és a vezetőség számára is. A tevékenységek priorizálását a WIP limitek biztosítják. Használatukkal egyik munkafázisban sem torlódnak fel a feladatok. Ha valahol elérik a maximumot, akkor ott nem lehet továbbhaladni az adott feladattal, és ilyenkor a munkatársak kölcsönösen segítik egymást - ezáltal biztosítva a projekt folyamatos és egyenletes elömenetelét. A harmadik fontos Kanban eszköz pedig a teljes átfutási idő mérése, ami a WIP limitek folyamatos változtatásával módosítható. Így ez egy hatásos mérőszám a rendszer optimalizálásához (Kniberg, 2007).

\section{eXtreme Programming (XP)}

Az eXtreme Programming egy szoftverfejlesztési módszertan, amelynek célja a változó körülmények mellett történő magas minőségü szoftver-előállítás. Rövid fejlesztési ciklusokat alkalmaz a gyors reagálás érdekében, és két ilyen ciklus között lehet alkalmazkodni a megváltozott követelményekhez. Az XP legfontosabb elemei: páros programozás (pair programming), kód felülvizsgálat (code review), egyszerü kódolás (simple code), majd a teljes kód tesztelése az éppen nem szükséges funkciók implementálásának mellözésével, valamint a gyakori kommunikáció mind az ügyféllel, mind a programozók között (Ellis, 2016).

\section{Empirikus kutatás az agilis módszertanok megítélésével kapcsolatban}

Nemzetközi szinten számos szakirodalom és publikáció található az agilitás fogalmához köthetően, amelyekből a legújabbak például az agilis módszertanok bevezetésének a szervezeti szabályokra tett hatásával foglalkoznak (Jovanović et al., 2017), vagy a megfelelő agilis projektmenedzsment-eszközök kiválasztásának és implementálásának a kérdéskörét vizsgálják (Rasnacis - Berzisa, 2017). Hazai szinten az agilis szemlélet első két évtizedét Klimkó áttekintő cikke kellő alapossággal körbejárja, ismertetve az agilitás témájának vezetéstudományi pozicionálását (Klimkó, 2014), azonban a szoftverfejlesztésben az agilis módszertanok megítélése a vezetők és a beosztottak szemszögéből egy olyan kutatási téma, amelynek a vezetéstudomány-központú feldolgozása még feltérképezetlen terület. A kérdéskör pedig releváns, hiszen az általános vezetési gyakorlat, illetve a közvetlen felettesi magatartás az, ami a teljes cég működésére, a szervezet teljesítményére és a dolgozók attitűdjére is kihatással van (Nemes - Szlávic, 2011).

A kutatás célja az agilis módszertanokat használó vállalkozások projektmenedzsment-módszereinek felmérésén keresztül a beosztottak és a vezető pozícióban dolgozók véleményének megismerése az agilis irányzattal, az ehhez használt eszközökkel és az így vezetett projektekkel kapcsolatban. 
A kérdéskör vizsgálatához először célszerü meghatározni azt, hogy pontosan milyen különbségek is adódnak a vezetők és az alkalmazottak között a különböző vezetéstudomány relevanciájú szakirodalmakban. Klein (2012) értelmezésében a vezetés egy adott feladat (kitüzött cél) megoldását jelenti, ami más emberek segítségével érhető el. A vezető tehát olyan célok megvalósítására veszi rá a beosztottjait, amelyben egyrészt a vezetői, másrészt a beosztottak céljai, szükségletei, értékei és várakozásai is megjelennek. A tevékenysége során a vezető kezdeményez, értékeli a beosztottak motivációit, előre jelzi a lehetséges válaszukat a kezdeményezésre, miközben felméri a hatalmi bázisukat. A sajátja mellett tehát figyelembe veszi a beosztottak szándékait és motivációjukat, hogy azok kielégítésével aktív szerepet vállaljon a motivációs szerkezetük fejlesztésében (Bakacsi, 2004). Így ennek érdekében a vezető az a személy, aki képes biztosítani azt, hogy a közös cél elérése érdekében a beosztottak vele elkötelezetten együttmüködjenek a képességeik, tehetségük, energiáik felhasználásával. A vezetés tehát egy olyan átfogó tevékenység, amely során a vezető az, aki eredményesen megvalósíttat különböző tevékenységeket a szervezet többi szereplöje (a beosztottak) által (Dobák - Antal, 2010). Ebben a rendszerben az emberi erőforráson túl, a használt eszközök azok, amelyek alapvetően befolyásolják a munkavégzés, az abban érintettek mindennapjait.

A teljes felmérés másodlagos adatgyüjtéssel indult, aminek a célja az agilis szoftverfejlesztéshez köthetö öszszes fogalom megismerése, mivel ezeknek a szintézise hiányzó szegmens a szoftverfejlesztéssel foglalkozó magyar szakirodalmakban, illetve ennek az áttekintése alapvetően releváns a kutatáshoz köthető független és függő változók meghatározása, és azok megértése érdekében. Ennek megfelelően az alkalmazott általános vizsgálati modellben független változó a cég jellemzői, a beosztás típusa, valamint maguk az alkalmazott agilis projektmenedzsment-eszközök. Függő (cél) változók pedig a megkérdezettek sikerkritérium megítélései az agilis módszertanokkal, a különböző eszközök alkalmazási tapasztalataival kapcsolatban.

A primer kutatás kérdöíves megkérdezés volt és online formában terjesztettük, elsősorban a kutatás elvégzésekor (2015 októberében) 1600 föt számláló, korábban AgileHungary nevü meetup csoportban (Budapest Agile Meetup, 2010), ahol a különböző hazai szoftveres cégek dolgozói, egyéni vállalkozók, illetve az agilis módszertanok iránt „,távolabbról” érdeklődő egyetemi hallgatók, valamint egyéb tagok vannak jelen. Az online közösség célja a személyes kapcsolatteremtés és az agilis gondolkodással kapcsolatos kötetlen információcsere támogatása. A csoport tagjai agilis módszertant alkalmazó magyarországi projektvezetők, rendszertervezők, fejlesztők és különböző szoftveres vállalkozások vezetői, így teljes mértékben egybeesnek a felmérés célcsoportjával. A kérdőív arra kereste a választ, hogy a különbözö agilis szervezetek milyen módszereket és azoknak mely elemeit használják, mennyire sikeres ezeknek az alkalmazása, és tapasztalható-e mérhető fejlődés a bevezetésük óta. Ezen kívül rákérdezett arra is, hogy a megkérdezettek mit tartanak az agilis módszerek, illetve a használt eszközök erősségeinek és gyengeségeinek. Ezek milyen hatással vannak a cég egészének müködésére, milyen sajátosságok jellemzők a vállalat termékfejlesztési folyamataira?

A kérdőív első része alapvető demográfiai kérdéseket (életkor, nem, legmagasabb iskolai végzettség) tartalmazott, illetve a foglalkoztatottság típusára kérdezett rá. A kutatás során a kérdőívet 118 fö töltötte ki (85\%-ban férfiak), akik föleg egyetemi vagy föiskolai végzettséggel rendelkeznek (mindössze $7 \%$ jelölte a középiskolát, $6 \% \mathrm{az}$ OKJ-s végzettséget és további $2 \%$ azt, hogy doktori fokozattal rendelkezik). A 118-ból csupán 2 kitöltő volt, aki nem ismerte a konkrét agilis módszertanokat, további 9 személy pedig soha nem dolgozott még ilyen projekten. A megkérdezettek 90\%-a tehát jelenleg vagy korábban már használta az agilis módszertanokat, a továbbiakban így ezzel a 107 fös mintával foglalkozunk. Az agilis módszertanok ismeröi közül $60 \%$ beosztottként, $32 \%$ pedig vezetőként dolgozik, olyan szoftverpiaci vállalatoknál, mint például az EPAM Systems, az Ericsson, a Nokia vagy a LogMeIn - a konkrét cég nevét a kitöltők szabad szöveges válasz formájában, opcionálisan adhatták meg. A minta további $6 \%$-a tevékenykedik egyéni vállalkozóként, a maradék $2 \%$ pedig egyéb foglalkoztatási módot nevezett meg (2. ábra).

\section{A vizsgált minta megoszlása foglalkoztatási módjuk szerint}

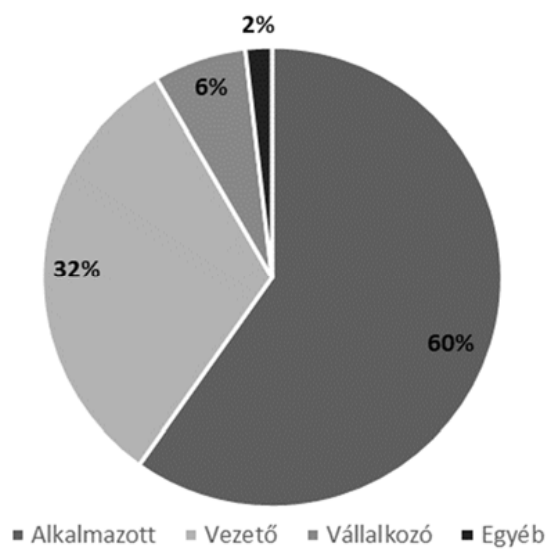

2. ábra

\section{oredmények}

A publikációk között ugyan található olyan vezetéstudomány központú kutatás, amely részletesen vizsgálja a projektvezető vezetési stílusának hatását a projektsikerre, méghozzá egy olyan vállalat példáján keresztül, amely az adatfelvétel idején tért át az agilis projektvezetési módszertanok alkalmazására, de a kapott eredmények nem általánosíthatók, hiszen abban csak egy vállalat szolgáltatta a mintát (Blaskovics, 2015). Így a kérdőív második része a sikeresség és sikertelenség általános okainak feltárását és a különböző agilis projektmenedzsment módszertanok népszerüségének, alkalmazási megítélésének, bevezetési körülményeinek feltárását tűzte ki célul. 
A megkérdezettek közül mindössze 5 fö (4,2\%) gondolta úgy, hogy az agilis projektek cégüknél kevésbé vagy egyáltalán nem sikeresek, a többiek szerint az agilis fogalom inkább vagy egyértelműen összeköthető a sikerességgel. Tipikusan a kisebb cégeknél dolgozó beosztottak válaszolták azt, hogy sikertelenebbek a szervezeten belüli (formálisan) agilis projektek. Ebben az esetben szerintük a problémát az okozta, hogy a cégen belül nincs tanúsított szakember vagy a projektek során formálisan csak a Scrum Master szerepkört töltötték be.

A kérdőív szabad szöveges válaszok formájában térképezte fel, hogy mi lehet a sikeres agilis projektek legfőbb oka, amire a következő általános válaszok születtek:

- rugalmasság, gyors reakció, alkalmazkodás,

- folyamatos visszajelzések, újratervezés,

- agilitásra nyitott szervezet, csapat és ügyfél,

- transzparencia,

- gyorsabb piacra jutás.

A válaszok alapján elmondható továbbá, hogy az agilis módszertanok sikeréhez az alábbi konkrét tényezők járulnak még leginkább hozzá:

- a megfelelö részletességü tervezés, komplexitás lebontása, és a fegyelmezett Napi Stand-up (Napi Scrum) megbeszélések nagymértékben hozzájárulhatnak a sikerhez,

- a feladatok minél kisebb egységekre bontása által sokkal átláthatóbb, hogy mi az, amit szállítani kell, így a változásokra is sokkal gyorsabban lehet reagálni, valamint probléma esetén könnyebb az irányváltás,

- a sikeresség oka annak az elfogadásában rejlik, hogy elsőre lehetetlen tökéletes rendszert tervezni, mivel az igények menet közben is sokat változhatnak akár a piac szempontjából, akár a megrendelőt tekintve. Ezt kell elfogadni ahhoz, hogy a csapat megfelelö mértékben rugalmas tudjon lenni.

Hasonlóan vizsgálva a sikertelen agilis projektek legfőbb okai között pedig az alábbi válaszok szerepelnek:

- a nem megfelelö tervezés, elsősorban a feladatok rossz becslése okozhatja a projekt sikertelenségét,

- ha a szervezet csak névlegesen alkalmazza az agilis módszertanokat, de valójában inkább a klasszikus modellek lépéseihez ragaszkodik,

- sokszor a vezetők, a fejlesztők vagy az ügyfél fejében kell a problémát keresni. Gyakori például a hibás vezetői elvárások megléte. Ez a beosztottakra is kihat, akik így nem látják át, hogy az agilitás hogyan fog segíteni, hogyan lehet hatékony. Tehát gyakori probléma a maradi gondolkodás megléte, vagy éppen az agilis tudás, tapasztalat hiánya.

Arra a kérdésre, hogy mióta alkalmazzák az adott cégnél az agilis módszereket a kitöltők mindössze 19\%-a jelölte azt a választ, hogy azok több mint öt éve vannak jelen, a megkérdezettek 26\%-ánál pedig 3-5 évvel ezelőtt vezették be azokat. A legtöbben (ez 41\%-ot jelent) csak 1-3 éve, a maradék 14\%-nál pedig kevesebb, mint egy éve alkalmazzák az agilis irányelveket. A válaszokból jól látható, hogy viszonylag új projektmenedzsment-módszertanokról van szó.

\section{3. ábra}

A vizsgálati minta megoszlása az agilis módszertanok bevezetési ideje szerint

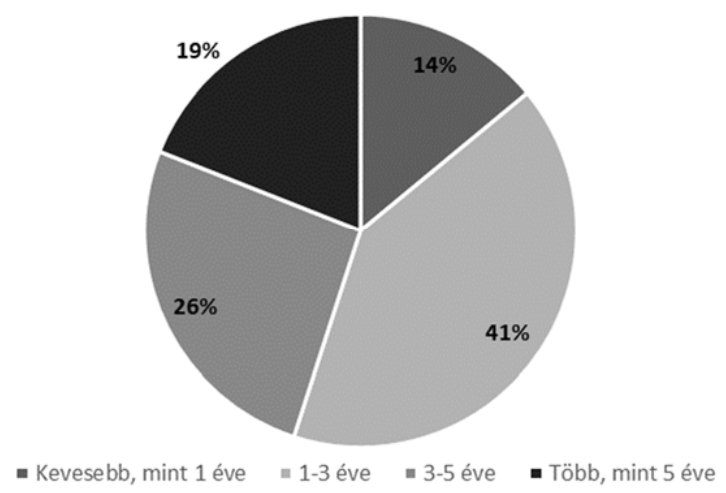

A 3. ábrán látható eredmény nem meglepő, hiszen az agilis „mozgalom” a 90-es évek végén kezdett el terjedni Amerikában, Magyarországra pedig csak a 2000-es évek végén jött be ez az irányzat. A fejlesztésben történő módszertani váltás ráadásul komoly felsővezetői döntés, ami nagyfokú szervezeti átalakítást is igényel.

A kérdőív harmadik része a konkrét agilis módszertani eszközök használatára kérdezett rá, azoknak a népszerüségét mérte. A módszertani eszközöket tekintve jelen mintáról elmondható, hogy a Scrum keretrendszert a vállalkozások 94\%-a alkalmazza, a Kanbant 65\%, míg az eXtreme Programming módszertant 40\% (4. ábra).

4. ábra

A megkérdezettek szervezeti egységeinél alkalmazott agilis módszertani eszközök népszerűsége

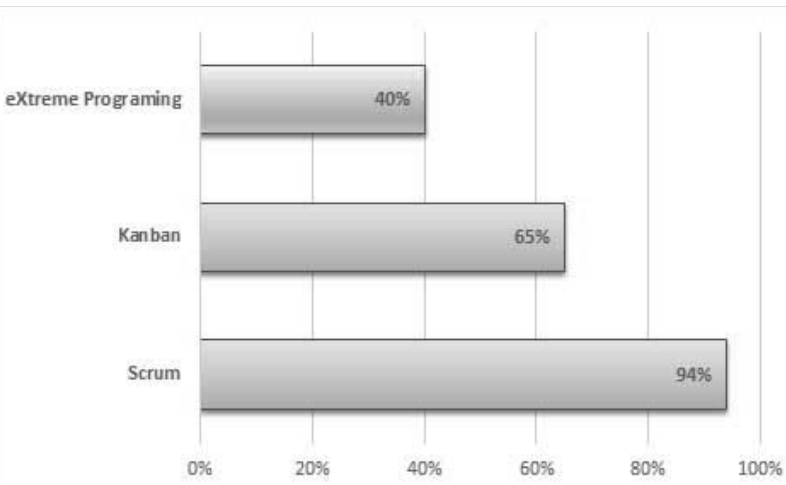

Mivel a különféle módszertanok keretrendszereket definiálnak csupán, így a valós gyakorlatban a cégeknél ezeken belül vezetői döntések alapján választják ki azokat az alkalmazni kívánt eszközöket, amelyekkel a beosztottak dolgozni fognak a hatékony munkavégzés érdekében. Az alkalmazott Scrum technikák közül a Sprint tervezés és 
a Napi Stand-up (Napi Scrum) voltak az első két helyen, amelyet a vállalatok 90\%-a használ előszeretettel. Ezután következik szorosan a Backlog tervezés és a Review megbeszélés $80 \%$ körüli értékkel. Itt az 50\%-os értéket még az elkészült kódrészletek gyakori bemutatása, illetve a Burndown Chart grafikon alkalmazása haladta meg. A csapat sebességének mérését a cégek mindössze 43\%-a alkalmazza. A Kanban elemei közül 58\%-ban használják a vizualizációt, valamint 37\%-ban a WIP limitet, és csak 29\%-ban az átfutási idő mérését. Az XP technikák közül pedig a Pair programming végzett az első helyen 36\%-kal.

Arra a kérdésre, hogy hivatalosan van-e agilis szerepkört betöltő szakember a cégben, kimagaslott a Scrum Master válasz 56\%-kal, melyet a Product Owner követett (35\%). Mindössze a szervezetek 39\%-a jelölte, hogy egyáltalán nincs a cégen belül ilyen szakember, azonban 25\%uk úgy gondolja, hogy ,on the job” jelleggel a szerepkör megfelelö tapasztalattal betölthető.

\section{Eredmények a beosztottaknál és a vezetőknél}

A kitöltők közül a beosztottak 56\%-a tartozik a 35 év alatti kategóriába, míg a vezetőknél ugyanez az arány 42\%-ra tehető. Tekintve, hogy a vezetői pozíciókhoz nagyobb tapasztalatra és tudásra van szükség (a szoftverfejlesztés területére különösen igaz, hogy a megfelelö hozzáértés és kompetencia csak elegendő idő elteltével szerezhető meg), így ezzel magyarázható, hogy 35 év fölött már nagyobb arányban vannak jelen a vezetői beosztásban levő emberek.

A legtöbb kitöltés (beosztottak esetén 47, míg a vezetőknél 35 százalékban) 250 fő feletti nagyvállalatoktól érkezett. A beosztottak negyede, a vezetőknek pedig közel a fele (amely kimagasló értéknek tekinthetö) 51 és 250 fö közötti munkavállalóval rendelkező szervezetekben (középvállalatokban) tevékenykedik. Az agilis módszertanok megítéléséről nyilatkozó kitöltők 22\%-a dolgozik 10 és 50 fö közötti kisvállalatoknál beosztottként, míg 15\% vezetői pozíciót tölt be. A kitöltési arány a 10 fö alatti mikrovállalatok esetén igen alacsony, ilyen cégeknél agilis módszertanokkal mindössze a megkérdezettek 6-6\%-a dolgozik (5. ábra).

\section{A minta összetétele a különböző vállalati méretkategóriák alapján}
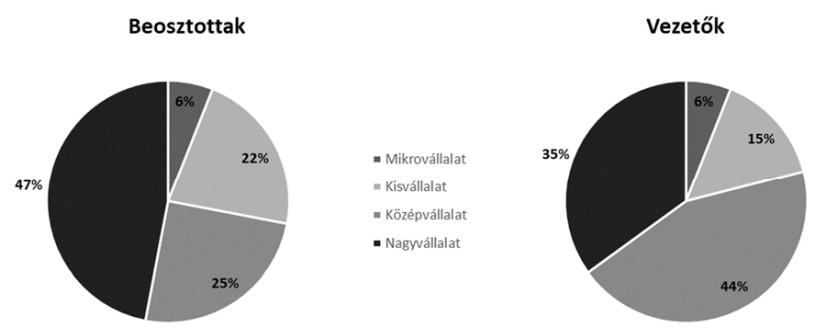

A 250 fö fölötti nagyvállalatok (tipikusan multinacionális cégek) a legdinamikusabban fejlődő vállalkozási formák közé tartoznak. Közös jellemzőjük, hogy gyakran bekapcsolódnak a cégszinten indított (például az agilis fejlesztéshez köthető) tudásmenedzsment projektekbe, amivel a céljuk, hogy gazdasági erőfölényre tegyenek szert a különböző piacokon (Chikán, 2006). Méret alapján pedig a fejlődésben levő - tipikusan kevesebb szoftvertermékre koncentráló - hazai középvállalatok azok még, ahol az agilis módszertanok alkalmazása biztosan nagyban javíthat a hatékonyságon.

Az agilis módszertanok kevésbé lehetnek hatékonyak azoknál a kisebb szervezeteknél, ahol már nem feltétlenül szempont a tudás tárolása és átadása (például a megfelelö hozzáállás hiánya, vagy az alacsonyabb bérköltségek miatt, vagy azért, mert a cégek kisebb létszám esetén nagyobb eséllyel bíznak a tervezett tudásmenedzsment nélküli, informális tudásátadásban, alacsony fluktuációt remélve) (Chikán, 2006).

Egy agilis csapat ideális esetben 5-9 föböl áll. Ennél nagyobb csoportban már nem alakul ki a csapatszellem, vagy több csapatot kell létrehozni, amelyek között kommunikációs problémák léphetnek fel. A csapattagok ideális esetben egy térben dolgoznak és többféle kompetenciával rendelkező tagokból állnak (Ficsor et al., 2013). 10 fö alatti vállalatnál az alkalmazottak egy agilis csapatként tevékenykednek, azonban, ha a vállalat operatív szoftverfejlesztésben részt vevő beosztottak száma ötnél kevesebb, akkor a módszertan már nem müködik jól - legfeljebb egyes elemeinek az alkalmazása segíthet.

A szoftverpiacon történő versenyben maradáshoz fontos szempont az ügyféligényekhez való alkalmazkodás a szervezeti egység méretétől függetlenül. Mivel ehhez az agilis módszertanok nagyban hozzájárulnak, így a fenti jellemzők ismeretében nem meglepő, hogy a mintában ilyen arányban jelennek meg a különböző vállalati méretkategóriák.

A válaszadók profilja az érintett cégeknél legnagyobb részben egyedi szoftver- és webfejlesztés, de ezen túl a vezetők válaszai között kimagasló értékkel (42\%) szerepel a kutatás-fejlesztési tevékenység is, míg ez a beosztottaknál már csak 22\%-ban jellemző. A kutatás-fejlesztés válasz megjelölése leginkább a foglalkoztatási móddal áll összefüggésben, ebben az esetben ugyanis a vezetők és a beosztottak között Mann-Whitney próbát alkalmazva nem szignifikáns, de tendenciózus eltérés tapasztalható ( $\mathrm{Z}=$ -1,830; $p=0,067)$. Ugyanezt vizsgálva a különböző vállalati méretkategóriák alapján az eltérés még távolabb van a szignifikánstól (középvállalat, illetve nem-középvállalat bontásban $\mathrm{p}=0,130$; míg a nagyvállalati tényezőt, mint csoportosító változót alapul véve ez a valószínüségi érték pedig 0,551). Az IT-tanácsadás és a mobilalkalmazások fejlesztése pedig beosztástól függetlenül 20 és 30\% között van jelen.

A szerepkörökben a beosztottaknál a Scrum Master pozíció a domináns 30\%-kal. Mivel a jellemzően 5-9 fős Scrum csapatokban mindig pontosan egy Scrum Master van, az első közelítésben azt jelentené, hogy ideális esetben a válaszadók 11-20\%-a lenne Scrum Master. Az, hogy ennél nagyobb százalékban jelölték meg, elsősorban abból adódik, hogy ez nem egy rögzített munkakör, azaz ezt a 
szerepet különböző projektekben különböző személyek tölthetik be. Tehát egy teamben ugyan aktuálisan csak egy Scrum Master dolgozik, de a többi csapattag között is vannak olyanok, akik más projektben is Scrum Master szerepet kaptak (Anand - Dinakaran, 2016). Ez a módszertan alkalmazásának érettségét jelzi.

A beosztottaknál a második leggyakoribb a senior fejlesztői pozíció (28\%), majd ezt követi a junior fejlesztő és a projektmenedzser beosztás $14-14 \%$-kal. A Product Owner szerepkört betöltő szereplők mindössze a minta $9 \%$-át, Business Analyst beosztás pedig a 6\%-át teszi ki.

Vezetőknél az első helyen hármas holtverseny alakult ki a betöltött szerepekben, így a válaszok között a Product Owner, a Scrum Master és a Projektmenedzser egyaránt $32 \%$-kal van jelen, amit a Business Analyst szerepkör követ $13 \%$-kal.

A Product Owner szerepkört a teljes minta $15 \%$-a jelölte be, ami megfelel az elvárásoknak, hiszen, ha a jellemzően 5-9 fös Scrum team tagjai között a gyakorlatban mindig pontosan egy Product Owner van, akkor ez az érték ideális esetben 11 és 20 százalék között mozog. A beosztottaknál jelenlevő $9 \%$ ennek a közelében van, viszont a vezetőknél ugyanez az érték lényegesen magasabb. Mivel ez a szerepkör (a már ismertetett feladatok jellege miatt) nagy felelösséggel jár, így annak a betöltése inkább a vezetőkre jellemző, amely statisztikailag is alátámasztható $(\mathrm{Z}=-2,845 ; \mathrm{p}=0,040)$.

A kapott válaszok alapján tehát jól látszik, hogy a beosztottak inkább fejlesztőként dolgoznak a teamen belül, míg a vezető beosztásúak tipikusan a nagyobb felelősséggel járó (Product Owner, Projektmenedzser, Business Analyst, Scrum Master) szerepkörökben vannak jelen (1. táblázat). Ezek közül a Scrum Master az egyetlen olyan szerep, amelyet beosztottak és vezetők is egyaránt nagy arányban töltenek be.

1. táblázat

\section{Kereszttábla (beosztás-szerepkör)}

\begin{tabular}{|c|c|c|c|c|c|}
\hline & & & Sze & repkör & \\
\hline & & & $\begin{array}{c}\text { Fej- } \\
\text { lesztői }\end{array}$ & $\begin{array}{l}\text { Nagyobb } \\
\text { felelősségű }\end{array}$ & $\begin{array}{l}\text { Ussze- } \\
\text { sen }\end{array}$ \\
\hline & Peogratt & $\begin{array}{l}\text { Elemszám } \\
\text { (fó) }\end{array}$ & 29 & 27 & 56 \\
\hline & Beosztott & $\begin{array}{l}\text { Százalékos } \\
\text { érték }\end{array}$ & $51,8 \%$ & $48,2 \%$ & $100 \%$ \\
\hline Beosztas & Vezetö & $\begin{array}{l}\text { Elemszám } \\
\text { (fö) }\end{array}$ & 2 & 20 & 22 \\
\hline & Vezeto & $\begin{array}{l}\text { Százalékos } \\
\text { érték }\end{array}$ & $9,1 \%$ & $90,9 \%$ & $100 \%$ \\
\hline
\end{tabular}

Mivel az agilis módszerek nagyobb hangsúlyt fektetnek a közvetlen kommunikációra, mint az írásbelire, így fontos kérdés, hogy az ezt támogató megbeszélések (például Napi Stand Up, Review) és az agilis müködés adminisztrációjának (Burndown Chart, KanBan tábla, különböző backlog listák aktualizálása) mennyiségi megítélése mennyiben változik a beosztottak és a vezetők szemszögéből. A beosztottak 64,1\%-a tartja megfelelő mértékünek a megbe- szélések számát, és 12,5\% gondolja úgy, hogy arra jóval kevesebb idő jut, mint kellene (23,4\% szerint tehát az túl sok időt vesz el). A vezetőknek pedig az 58,1\%-a gondolja azt megfelelőnek, és mindössze $6,5 \%$ érzi, hogy arra több időt kéne fordítani, így 35,5\% tartja a szükségesnél többnek az erre fordított időt (2. táblázat).

2. táblázat

Kereszttábla (beosztás - megbeszélések mennyisége)

\begin{tabular}{|c|c|c|c|c|c|c|}
\hline & & & \multirow{2}{*}{\multicolumn{3}{|c|}{ Megbeszélések mennyisége }} & \multirow[b]{3}{*}{$\begin{array}{c}\text { Össze- } \\
\text { sen }\end{array}$} \\
\hline & & & & & & \\
\hline & & & $\begin{array}{c}\text { Keve- } \\
\text { sebb }\end{array}$ & $\begin{array}{l}\text { Meg- } \\
\text { felelö }\end{array}$ & Több & \\
\hline \multirow{4}{*}{ 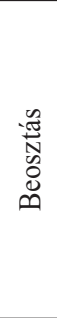 } & \multirow{2}{*}{$\begin{array}{l}\overrightarrow{0} \\
\stackrel{0}{N} \\
0 \\
0 \\
D \\
\infty\end{array}$} & \begin{tabular}{|l|}
$\begin{array}{l}\text { Elemszám } \\
\left(\mathrm{foo}^{\prime \prime}\right)\end{array}$ \\
\end{tabular} & 8 & 41 & 15 & 64 \\
\hline & & \begin{tabular}{|l} 
Százalékos \\
érték
\end{tabular} & $12,5 \%$ & $64,1 \%$ & $23,4 \%$ & $100 \%$ \\
\hline & \multirow{2}{*}{$\begin{array}{l}=0 \\
\stackrel{0}{0} \\
\text { N } \\
>\end{array}$} & \begin{tabular}{|l}
$\begin{array}{l}\text { Elemszám } \\
\text { (fö) }\end{array}$ \\
\end{tabular} & 2 & 18 & 11 & 31 \\
\hline & & \begin{tabular}{|l|} 
Százalékos \\
érték
\end{tabular} & $6,5 \%$ & $58,1 \%$ & $35,5 \%$ & $100 \%$ \\
\hline
\end{tabular}

Az adminisztráció esetében már fordított a helyzet, ugyanis a beosztottak és vezetők is körülbelül 60\%-ban gondolták megfelelőnek annak a mennyiségét, azonban a beosztottak közel 30, míg a vezetőknek pedig 22,6\%-a gondolta túlzottnak (3. táblázat).

3. táblázat

Kereszttábla (beosztás - adminisztráció mennyisége)

\begin{tabular}{|c|c|c|c|c|c|c|}
\hline & & & \multicolumn{3}{|c|}{ Adminisztráció mennyisége } & \multirow[b]{2}{*}{$\begin{array}{c}\text { Össze- } \\
\text { sen }\end{array}$} \\
\hline & & & $\begin{array}{l}\text { Keve- } \\
\text { sebb }\end{array}$ & $\begin{array}{c}\text { Megfe- } \\
\text { lelö }\end{array}$ & Több & \\
\hline \multirow{4}{*}{ 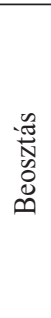 } & \multirow{2}{*}{\begin{tabular}{l} 
\pm \\
\multirow{0}{0}{} \\
N \\
0 \\
0 \\
0
\end{tabular}} & \begin{tabular}{|l|} 
Elemszám \\
(fó)
\end{tabular} & 7 & 38 & 19 & 64 \\
\hline & & \begin{tabular}{|l}
$\begin{array}{l}\text { Százalékos } \\
\text { érték }\end{array}$ \\
\end{tabular} & $10,9 \%$ & $59,4 \%$ & $29,7 \%$ & $100 \%$ \\
\hline & \multirow{2}{*}{$\begin{array}{l}: 0 \\
\stackrel{0}{0} \\
\stackrel{N}{D}\end{array}$} & \begin{tabular}{|l|} 
Elemszám \\
(fo)
\end{tabular} & 6 & 18 & 7 & 31 \\
\hline & & \begin{tabular}{|l|}
$\begin{array}{l}\text { Százalékos } \\
\text { érték }\end{array}$ \\
\end{tabular} & $19,4 \%$ & $58,1 \%$ & $22,6 \%$ & $100 \%$ \\
\hline
\end{tabular}

A jelenlegi mintában nem volt különbség a megkérdezettek válaszai között az agilis módszertanok során a megbeszélésekre és az adminisztrációra fordított idő mértékének megítélésben, így az az agilis módszerekkel dolgozó beosztottak és vezetők számára egyaránt megfelelőnek mondható (4. táblázat).

4. táblázat

Pearson-féle khí-négyzet próba a megbeszélésekre és az adminisztrációra fordított idő mértékének megítélésére

\begin{tabular}{|c|c|c|c|c|}
\cline { 2 - 5 } \multicolumn{1}{c|}{} & \multicolumn{2}{c|}{ Megbeszélések mennyisége } & \multicolumn{2}{c|}{ Adminisztráció mennyisége } \\
\cline { 2 - 5 } \multicolumn{1}{c|}{} & Érték & Szignifikancia & Érték & Szignifikancia \\
\hline $\begin{array}{c}\text { Khí-négyzet } \\
\text { (Pearson) }\end{array}$ & 1,954 &, 376 & 1,473 &, 479 \\
\hline Elemszám(N) & 95 & & 95 & \\
\hline
\end{tabular}


A beosztásbeli különbségekből adódóan azonban a megbeszélések mennyiségét a vezetők, az adminisztráció mértékét pedig a beosztottak tartják többnek, mint amennyire szükség lenne. Ez nem meglepő, hiszen a vezetőnek elengedhetetlen a folyamatos státuszjelentések megléte, hogy a projektek haladását követni tudják, ami viszont a tényleges fejlesztéstől veszi el sok esetben az időt. A beosztottak szemszögéből nézve pedig szükség van a rendszeres, ütemezett és minél részletesebb megbeszélésekre, hogy visszaigazolást nyerjenek arról, hogy jó irányba haladnak, vagy választ kapjanak a felmerülő kérdéseikre, aminek a túlzott mértéke vezetői oldalról nézve pedig a hasznos munkavégzéstől vonja el az időt.

A betöltött pozíció függvényében fontos kérdésnek bizonyult az is, hogy a megkérdezettek szerint milyen igények motiválták az agilis módszertanok bevezetését. Itt a beosztottak és vezetők válaszai között az első három helyen mutatkoztak eltérések.

A vezetők 74\%-a szerint ugyanis első helyen áll az ügyfél igényeinek rugalmasabb kezelése, majd ezt követi a magasabb minőség iránti igény (68\%), végül harmadik helyen (52\%-ban) vélték úgy, hogy ez az igény alulról érkezett, így az agilis módszertanok a hatékonyabb munkavégzést támogatják.

A beosztottak megítélése szerint pedig első helyen áll a magasabb minőség iránti igény (53\%), majd utána 48\%uk gondolta úgy, hogy a kezdeményezés alulról érkezett, végül a harmadik helyen az ügyféligények rugalmasabb kezelése áll (45\%). Az adatokból az látható, hogy a beosztottak kiegyenlítettebben jelöltek, náluk a válaszokban az első négy hely között nem volt igazán kimagasló érték, míg a vezetőknél az első két szempontot a kitöltők több, mint kétharmad része jelölte meg. Tehát számukra ezek az igények kimagaslóan fontosak (6. ábra).

Az agilis módszertanok bevezetési okai a beosztottak és a vezetők szemszögéből

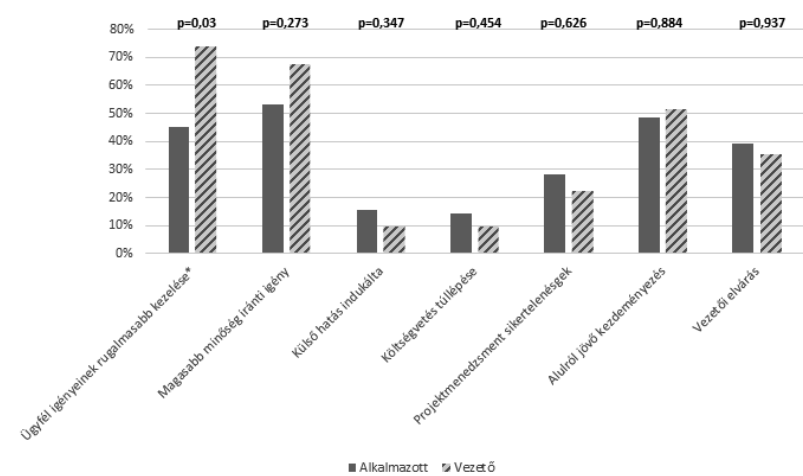

Az agilis módszertanok bevezetése során a beosztottak szerint nagy segítséget jelentett, hogy céges szintű képzést tartottak, tréningeken vettek részt és közben saját maguk alakították ki a folyamataikat. Ezeket a szempontokat az beosztottak több mint 50\%-a minden esetben megjelölte. A vezetőknél az első három helyen ugyanezeket a szempontokat azonosították, viszont közben a saját folyamatok kialakításának fontossága nagyobb mértékben (75\%-ban) szerepelt segítő tényezőként. A bevezetés során „,agilis coach", mint szakértő a beosztottak mindössze 34, a vezetőknek pedig 39\%-át segítette. Ez az érték egybevág a (felmérés ideje alatt keletkező) 2016-os agilis körkép adataival, ahol a megkérdezettek a sikeres bevezetés releváns tényezőjeként jelölték meg a teljes munkaidőben jelenlevő agilis tréner szerepét (VersionOne, 2016).

A kapott eredményekből levonható az a következtetés, hogy a válaszadók az agilis módszertannal vezetett projekteket sikeresebbnek gondolják a hagyományosnál, ezt a beosztottak 94, míg a vezetők 100\%-a gondolja így.

A kutatás az agilis módszertan előnyeire is rákérdezett, a felsorolt nyolc tényező között a különböző szereplőknél az alábbi sorrend állapítható meg a rangsorösszegek alapján:

$\quad$ Beosztottak:
1. Rugalmasság
2. Megfelelö termék
3. Megrendelöi elégedettség
4. Gyorsabb piacra jutás
5. Minőség
6. Költségkontroll
7. Átláthatóság
8. Kockázatmenedzsment

1. Megrendelői elégedettség

2. Megfelelö termék

3. Minőség

4. Átláthatóság

5. Költségkontroll

6. Rugalmasság

7. Gyorsabb piacra jutás

8. Kockázatmenedzsment $\quad$ 8. Kockázatmenedzsment

A két rangsor között $\mathrm{W}=0,7$ értékủ a Kendall-féle rangkonkordancia együttható értéke, ami „erös közepes” egyezésre utal, de mivel a különbség nem szignifikáns $(\mathrm{p}=0,208>0,05)$, így a hasonlóság mértéke statisztikailag nem megbízható. Tehát a vezetők és a beosztottak értékelése eltérö. Látható, hogy a rangsor elején azonos helyre csak a megfelelő termék létrehozásának lehetősége került, ami az iterációknak és folyamatos visszajelzéseknek köszönhetően érhető el.

A kérdőíves megkérdezés vizsgálta azt is, hogy mi lehet a sikertelen agilis projektek legföbb oka, hiszen a sikeresség gyakran a projektvezető és a projektcsoport tagjainak mesterségbeli tudásán múlik (Daróczi, 2011). Itt ennek az állításnak megfelelő válaszok érkeztek: a vezetők legnagyobb arányban azt jelölték meg, hogy ebben az esetben az ő irányukból nincs megfelelő támogatás, vagy magát a projektszervezetet nem sikerült ideálisan kialakítani. A beosztottak közel negyede gondolja úgy, hogy a sikertelenség legföbb oka, hogy az ügyfél nem elég nyitott az agilis működés irányába, további $20 \%$ pedig szintén a projektszervezettel kapcsolatos belső múködési problémát azonosította. Elmondható tehát, hogy közel azonos súllyal ez az a három tényezö, amely a sikertelen agilis projektek legfőbb magyarázataként azonosítható.

\section{Összegzés}

Az eredmények megerösitették, hogy a beosztottak inkább (junior vagy szenior poziciójú) fejlesztöként vannak jelen a különbözö szoftvercégek életében, mint team tagok. A vezetök pedig tipikusan a nagyobb felelösséggel járó szerepköröket (ami az agilis szerepeket tekintve Product 
Owner, Scrum Master pozíció lehet) töltik be a szervezetek életében. Az agilis szerepköröknél elmondható, hogy egyedül a Scrum Master az, amit a beosztottak és vezetők is egyaránt nagy arányban töltenek be.

A különböző válaszokból jól látható, hogy a cégek igen változatos agilis projektmenedzsment-eszközöket alkalmaznak a vállalati gyakorlatban, ami egyrészt a módszertan gazdag eszköztárának köszönhetö, másrészt annak az érettségére utal. A megkérdezettek ezeket az agilis eszközöket egyértelmüen hatékonynak és sikeresnek gondolják az általuk betöltött pozíciótól függetlenül.

Az agilis módszerek általános jellemzői, hogy azok alkalmazásai nagyfokú adminisztrációt és gyakori megbeszélést igényelnek, amelyben a csapattagok és a vezetők is egyaránt érintettek. Az agilis módszerek alkalmazásához köthetö adminisztráció (például Burndown Chart, KanBan tábla, különböző backlog listák aktualizálása) és a különböző megbeszélések (például Napi Stand-up, Review) mértékét a beosztottak és a vezetők is egyaránt megfelelönek találják. Ez az agilis módszertani eszközök kiforrottságát és megfelelőségét igazolja.

A vezetök szerint az agilis módszertanok bevezetését első körben az ügyfél igényeinek rugalmasabb kezelése, majd a magasabb minőség iránti igény, végül az alulról érkezö nyomás (igy a hatékonyabb munkavégzésre való dolgozói törekvés) generálta. A beosztottak erröl a kérdésröl hasonlóan vélekedtek, azonban náluk már eltérö sorrendben és lényegesen kisebb súllyal szerepelnek a tényezők (1. minőség, 2. alulról érkező nyomás, 3. ügyféligények kezelése). Ez a sorrend arra utal, hogy az agilis módszertanok bevezetése nagyrészt a beosztottaknak köszönhetö, akik a hatékonyabb munkavégzés következtében képesek az előállított szoftvertermékek minőségének a növelésére, amely egyértelműen összefügg az ügyféligények rugalmasabb kezelésével. Ezt a tényezőt a vezetők ügyfélközpontú gondolkozása sorolta elöre, de annak a fontosságát a beosztottak is egyértelmüen látják (ahova a minőség növelésével juthatnak el).

Az agilis módszertanok alkalmazásának legföbb előnyei között beosztástól függetlenül kulcsfontosságú a megrendelöi elégedettség, és az, hogy a használatukkal a szervezet biztosan megfelelö szoftverterméket tud kialakitani, de a vezetók és a beosztottak megitélése teljesen eltérő. Például a különböző előnyök rangsorolása során a rugalmas reagálási képességet, mint agilis kulcstényezőt a beosztottak az első helyre sorolták, míg ez a vezetőknél a lista végére (a hatodik helyre) került. További jelentős eltérések a termék gyorsabb piacra jutásának megítélésében és az agilis rendszer átláthatóságának fontosságában akadtak (előbbi a beosztottak esetén három hellyel feljebb, utóbbi pedig ugyanennyivel lejjebb szerepel a vezetői rangsorhoz képest).

Összességében elmondható, hogy a szoftverpiacon az agilis eszközök egyértelmüen összefüggésbe hozhatók a hatékony munkavégzés fogalmával. Az agilis fejlesztés bevezetése és alkalmazása hozzájárul a hatékonyság és a minőség növeléséhez, amelyet a kutatás is alátámaszt, hiszen a beosztottak és vezetők az agilis módszertanokkal vezetett projekteket egyaránt sikeresebbnek gondolják, mint a hagyományos modelleket követöket. Fontos megemlíteni, hogy nem létezik két azonos cég, így az agilis módszertanok nem feltétlenül alkalmazhatók minden esetben jól (vannak olyan speciális szoftvertermékek, ahol elengedhetetlen a követelmények precíz definiálása és a „merev" fejlesztés). Ahol azonban van rá lehetőség, ott az agilis módszerek alkalmazására a véleményünk szerint az a legjobb gyakorlat, ha minden szervezet kiválasztja magának, hogy az agilis módszertanok mely elemeit szeretné használni, és ezeket vegyíti egymással, ugyanis mindegyikben vannak olyan elemek, amelyek a felgyorsult technológiai fejlödés követéséhez elengedhetetlenek.

\section{A kutatás korlátai és további lehetőségek}

Jelen kutatás legfóbb korlátja, hogy a gyakorlatban az agilis módszertanok bevezetése és a különböző eszközök alkalmazása számos olyan kérdést vet fel, amit nem lehet elég alaposan és jól mérni kérdőíves megkérdezés segítségével. Emiatt a következő kutatásunk (jelen eredményekre támaszkodva) interjúsorozat keretein belül tárja fel részletesebben a szoftvercégek jelenlegi gyakorlatát, ismerteti az agilis módszertanok magyarországi alkalmazásának helyzetét, kitérve az ott alkalmazott modellek, valamint a használhatósággal és felhasználói élménnyel kapcsolatos módszerek integráltságára is (Szabó - Hercegfi, 2017).

\section{Felhasznált irodalom}

Anand R. V. - Dinakaran M. (2016): Popular agile methods in software development: Review and analysis. International Journal of Applied Engineering, 11 (5), p. 3433-3437.

Anderson D. J. (2007): Kanban: Successful evolutionary change for your technology business. Washington: Blue Hole Press

Beck, K. - Beedle, M. - Bennekum, A. - Cockburn, A. - Cunningham, W. - Fowler, M. - Grenning, J. - Highsmith, J. - Hunt, A. - Jeffries, R. - Kern, J. - Marick, B. - Martin, R. C. - Mellor, S. - Schwaber, K. - Sutherland, J. - Thomas, D. (2001): The Agile Manifesto. Software Development Magazine, Volume 8, p. 1-7.

Bakacsi Gyula (2004): Szervezeti magatartás és vezetés. Budapest: AULA Kiadó

Blaskovics Bálint (2015): A projektvezető vezetési stílusának hatása a projektsikerre - egy hazai vállalat példája alapján. Vezetéstudomány/Budapest Management Review, 46 (8), p. 14-23.

Boehm B. (2002): Get ready for agile methods, with care. Computer Journal, 35 (1), p. 64-69.

Budapest Agile Meetup Group (2010): A Budapest Agile Meetup Group honlapja. Alapítás dátuma: 2010. április 7. Elérhető: http://www.meetup.com/AgileHungary/ (megtekintve: 2015.október 20.)

Bunyakiati P. - Surachaikulwattana P. (2016): Fit between Agile practices and organizational cultures. Thailand: 13th International Joint Conference on Computer Science and Software Engineering, p. 1-6.

Chikán Attila (2006): Bevezetés a vállalatgazdaságtanba. Budapest: AULA Kiadó 
Chin, G. (2004): Agile project management: How to succeed in the face of changing project requirements. AMACOM

Cummins, $A-F$. (2017): The agile organization structure, in building the agile enterprise. MK/OMG Press, p. 301-332.

Daróczi M. (2011): Projektmenedzsment. Gödöllő: Szent István Egyetem

DeCarlo, D. (2004): Extreme project management: Using leadership, principles, and tools to deliver value in the face of volatility. San Fransisco: Jossey-Bass

Dingsøyr, T. - Nerur, S. - Balijepally, V. - Moe, N. B. (2012): A decade of agile methodologies: Towards explaining agile software development. The Journal of Systems and Software 85 (6), p. 1213-1221.

Dobák M. - Antal Zs. (2010): Vezetés és szervezés: Szervezetek kialakítása és müködtetése. Budapest: AULA Kiadó

Ficsor L. - Kovács L. - Kusper G. - Krizsán Z. (2013): Szoftvertesztelés. Miskolc: Miskolci Egyetem Gépészmérnöki és Informatikai Kar - Kelet-Magyarországi Informatika Tananyag Tárház projekt

Ellis, G. (2016): Chapter 8: Agile Project Management: Scrum, eXtreme Programming, and Scrumban. In: Project Management in Product Development. Boston: Butterworth-Heinemann, p. 223-260.

Furnham, A. (2006): The psychology of behaviour at work: The individual organization. London: Taylor \& Francis Group, Psychology Press

Jovanović, M. - Mas, A. - Mesquida, A-L. - Lalić, B. (2017): Transition of organizational roles in Agile transformation process: A grounded theory approach. Journal of Systems and Software, Volume 133, p. 174-194.

Jurca, G. - Hellmann, T. D. - Maurer, F. (2014): Integrating agile and user-centered design: A systematic mapping and review of evaluation and validation studies of Agile-UX, Agile Conference, p. 24-32.

Kiran, D. R. (2017): Chapter 1 - Total Quality Management: An overview. In: Total Quality Management. Boston: Butterworth-Heinemann, p. 1-14.

Klein S. (2012): Vezetés- és szervezetpszichológia. Budapest: Edge $2000 \mathrm{Kft}$.

Klimkó G. (2014): Az agilis szemlélet első két évtizede. Vezetéstudomány/Budapest Management Review, 45 (7-8)., p. 86-96.

Kniberg, H. (2007): Scrum and XP from the Trenches: Enterprise Software Development. New York: C4Media

Kosztyán Zsolt (2015): Költség- és időcsökkentési eljárások alkalmazása a projekttervezésben és a nyomon követésben. Vezetéstudomány/Budapest Management Review, 46.

Lei, H. - Ganjeizadeh, F. - Jayachandran, P. K. - Ozcan, $P$. (2017): A statistical analysis of the effects of Scrum and Kanban on software development projects. Robotics and Computer-Integrated Manufacturing, Volume 43, p. 59-67.

Losonczi D. (2010): Bevezetés a lean menedzsmentbe: a lean stratégiai alapjai. Budapest: Budapesti Corvinus Egyetem, Vállalatgazdaságtan Intézet Mühelytanulmány sorozat, 119. mühelytanulmány

Medinilla, Á. (2014): Agile Kaizen: Managing Continuous Improvement Far Beyond Retrospectives. Berlin: Springer-Verlag $\mathrm{GmbH}$.
Nemes F. - Szlávicz Á. (2011): A vezetés szerepe a dolgozói elégedettség alakulásában. Vezetéstudomány/Budapest Management Review, 42 (9)., p. 2-14.

Parker, G. M. (2015): Cross-functional teams. San Francisco: John Wiley \& Sons

Pataki B. (2014): Változásmenedzsment. Oktatási segédlet. Budapest: Budapesti Müszaki és Gazdaságtudományi Egyetem

Paulk, M. - Davis, N. - Maccherone, L. (2011): On empirical research into Scrum. Institute for Software Research, Pittsburgh: Carnegie Mellon University

Pintér R. (2007): Az információs társadalom: Az elmélettől a politikai gyakorlatig. Budapest: Gondolat Kiadó

Rasmusson, J. (2010): The Agile Samurai: How Agile Masters Deliver Great Software. New York: The Pragmatic Bookshelf

Schön, E. M. - Thomaschewski, J. - Escalona, M. J. (2017): Agile Requirements Engineering: A systematic literature review: Computer Standards \& Interfaces, 49 (1), p. 79-91.

Schwaber, K. - Sutherland, J. (2013): The Scrum Guide: The Definitive Guide to Scrum: The Rules of the Game.

Rasnacis, A. - Berzisa, S. (2017): Method for Adaptation and Implementation of Agile Project Management Methodology. Procedia Computer Science, Volume 104, p. 43-50.

Sommerville, I. (2010): Software Engineering. Boston: Addison-Wesley Publishing Company

Stare, A. (2014): Agile Project Management in Product Development Projects. Procedia - Social and Behavioral Sciences, Volume 119, p. 295-304.

Szabó, B. - Hercegfi, K. (2017): Research questions on integrating user experience approaches into software development processes. In: Baranyi Peter (szerk.): 8th IEEE International Conference on Cognitive Infocommunications (CogInfoCom). Debrecen, Magyarország, p. 243-246.

Taylor, F. W. (1983): Üzemvezetés - A tudományos vezetés alapjai. Budapest: Közgazdasági és Jogi Könyvkiadó

Tasi M. (2011): Vállalatirányítási rendszerek. Budapest: Edutus Föiskola

Turk, D. - France, R. - Rumpe, B. (2005): Assumptions underlying agile software development processes. Journal of Database Management, Volume 16, No. 4, p. 62-87.

VersionOne (2016): 10th Annual State Of Agile Development Survey. https://explore.versionone.com/state-of-agile/versionone-10th-annual-state-of-agile-report-2 (letöltve: 2018. 02. 23.)

VersionOne (2017): 11th Annual State Of Agile Development Survey. https://explore.versionone.com/state-of-agile/versionone-11th-annual-state-of-agile-report-2 (letöltve: 2017. 09. 23.)

Viscardi, S. (2013): The Professional Scrum Master's Handbook. Birmingham: Packt Publishing

Webster, F. (2006): Theories of the Information Society. New York: Routledge

Wysocki, R. K. (2009): Effective Project Management: Traditional, Agile, Extreme. London: Wiley 